\title{
Correction to: Panretinal photocoagulation after or prior to intravitreal conbercept injection for diabetic macular edema: a retrospective study
}

Wei Zhang ${ }^{*}$, Guiyang Zhao, Weijie Fan and Taihong Zhao

Correction to: BMC Ophthalmology 21, 160 (2021)

https://doi.org/10.1186/s12886-021-01920-8

Following the publication of the original article [1], we were notified that the corresponding author was incorrectly marked. This should have been Dr. Zhang instead of Dr.Weijie.

The original article has been corrected.

Published online: 10 May 2021

\section{Reference}

1. Zhang, et al. Panretinal photocoagulation after or prior to intravitreal

conbercept injection for diabetic macular edema: a retrospective study (2021). 2021:21:160. https://doi.org/10.1186/s12886-021-01920-8.

The original article can be found online at https://doi.org/10.1186/s12886021-01920-8

* Correspondence: weizhang_njmu@163.com

Department of Ophthalmology, Nanjing First Hospital, Nanjing Medical

University, 68 Changle Rd, Nanjing 210,006, China

(c) The Author(s). 2021 Open Access This article is licensed under a Creative Commons Attribution 4.0 International License, which permits use, sharing, adaptation, distribution and reproduction in any medium or format, as long as you give appropriate credit to the original author(s) and the source, provide a link to the Creative Commons licence, and indicate if changes were made. The images or other third party material in this article are included in the article's Creative Commons licence, unless indicated otherwise in a credit line to the material. If material is not included in the article's Creative Commons licence and your intended use is not permitted by statutory regulation or exceeds the permitted use, you will need to obtain permission directly from the copyright holder. To view a copy of this licence, visit http://creativecommons.org/licenses/by/4.0/ The Creative Commons Public Domain Dedication waiver (http://creativecommons.org/publicdomain/zero/1.0/) applies to the data made available in this article, unless otherwise stated in a credit line to the data. 